\title{
Arterial System Smooth Muscle Tissue
}

National Cancer Institute

\section{Source}

National Cancer Institute. Arterial System Smooth Muscle Tissue. NCI Thesaurus. Code C49330.

The smooth muscle tissue present in the tunica media which is the middle layer of the wall of the arterial system. 